\title{
Isotopic analyses, a good tool to validate models in the context of Marine Renewable Energy development and cumulative impacts
}

\author{
Raoux Aurore ${ }^{2,4}{ }^{*}{ }^{\text {, }}$ Pezy Jean-Philippe ${ }^{2}$, Ernande Bruno ${ }^{3}$, Niquil Nathalie ${ }^{1}$, Dauvin Jean-Claude ${ }^{2}$, \\ Grangeré Karine ${ }^{4}$
}

1 Unité Biologie des Organismes et Ecosystèmes Aquatiques (BOREA), MNHN, CNRS, IRD, Sorbonne Université, Université de Caen Normandie, Université des Antilles, CS 14032, 14000, CAEN, France

2 Normandie Univ, UNICAEN, UNIROUEN, Laboratoire Morphodynamique Continentale et Côtière, CNRS UMR 6143 M2C, 24 rue des Tilleuls, 14000, Caen, France

3 IFREMER, Laboratoire Ressources Halieutiques, 150 quai Gambetta, BP 699, 62321, Boulogne sur Mer, France

4 Unité Biologie des Organismes et Ecosystèmes Aquatiques (BOREA), MNHN, CNRS, IRD, Sorbonne Université, Université de Caen Normandie, Université des Antilles, CS 14032, 14000, CAEN, France

* Corresponding author : Aurore Raoux, email address : aurore.raoux@unicaen.fr

\begin{abstract}
:
As part of the energy transition, the French government is planning Offshore Wind Farm (OWF) constructions in the next decades. An integrated ecosystem approach of two future OWF sites of the Eastern English Channel (Courseulles-sur-mer and Dieppe-Le Tréport) was developed to model the marine ecosystems before the OWF implementation. Such ecosystem models allow simulating the possible reef and reserve effects associated to the presence of the farm, and to character the overall changes in the food-web functioning. This holistic view of OWF effects could be replicated on other sites and form the basis of an ecosystem based management of marine renewable energies. However, to use these models for management purpose, they need to be validated. In order to do so, stable isotope ratios of nitrogen were used for determining the accuracy of the effective trophic levels computed in these two models. Results showed that trophic levels estimated by the two models were consistent with the trophic levels estimated by the independent isotopic data. In the context of OWF development and cumulative impacts analysis, this step of validation of the models is essential for developing their use by management actors and policy makers.
\end{abstract}




\section{Graphical abstract}

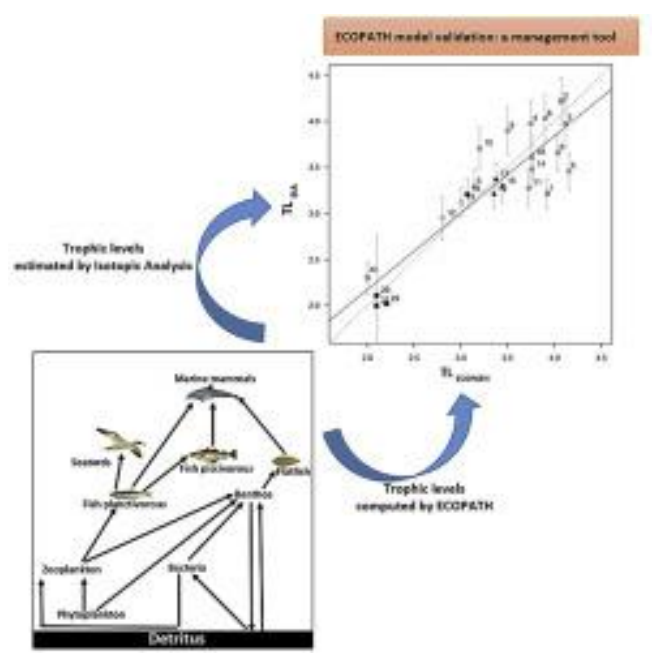

Highlights

- Comparison of trophic web structure by mass-balance modelling and stable isotopic approach. Clear relationships between trophic levels estimated by models and nitrogen value were found. Model validation is essential for developing their use by policy makers.

Keywords : Offshore Wind Farm, Ecopath with Ecosim, Trophic Level, Isotopic Nitrogen analysis, English Channel 
Clean renewable energy from Marine Renewable Energy (MRE) has increased steadily throughout the Northern Europe as a goal of reducing future carbon emissions. Of all MRE, Offshore Wind Farms (OWF) has seen consistent growth in capacity and it is by far the most technically advanced of all MRE (Leung and Yang, 2012; Willsteed et al., 2018). The French

40 government are currently planning the construction of three OWFs in the eastern basin of the English Channel (Fécamp, Dieppe-Le Tréport and Courseulles-sur-mer). Environmental impact studies following the $\mathrm{BACl}$ protocol are performed before the implementation, during the exploitation, and during the dismantlement, to investigate the impacts of these OWF structures on the surrounding marine ecosystems (Wilding et al., 2017). All these studies provide a large amount of data on environmental effects at the species level. However, as Raoux et al. $(2017,2019)$ pointed out, while these studies endeavour to consider the sensitivity of some ecological compartments (benthos, fish and marine mammals), they fail to do so if not taking into account the trophic links between the compartments. Thus, at the beginning of the OWF development in France, a research gap has been identified in the uncertainties around the potential impact of OWF installation on the trophic web structure and ecosystem functioning (Bailey et al., 2014). In this context, and as a complementary approach to the traditional impact assessments, there is a need to adopt an integrated ecosystem approach trough modelling tools that consider the ecosystem as a whole (Raoux et al., 2017, 2019; Pezy et al., 2018).

Quantitative trophic web models can be used for this purpose since they describe the interactions between species at different trophic levels (from prokaryote to top predators) and are based on the quantification of flows of energy and matter in ecosystems. Among these different existing approaches, the Ecopath with Ecosim (EwE) model has been intensively used and developed over the last three decades (Colléter et al., 2013, 2015) and was recognised by the US National Oceanographic and Atmospheric Administration (NOAA) as one of the ten biggest scientific breakthroughs in its 200 year history (Heymans et al., 2016). The EwE model has been used to analyse the impact of a wide range of anthropogenic perturbations on marine ecosystems through the world such as fishing activities (Heymans and Tomczak, 2016), invasion of species (Langseth et al., 2012), dumping operations (Pezy et al., 2017, 2018a), and infrastructure development (Tecchio et al., 2015). With the planning of 
the construction of three OWF, the English Channel has become a hotspot for future OWF development. Moreover, this area is one of the most human impacted area, with some of the highest cumulative impacts in the worldwide ocean (Halpern et al., 2008). Recently, Raoux et al. $(2017,2019)$ used the EwE approach in the context of OWF construction and cumulative impacts in the eastern part of the English Channel. In their study, Raoux et al $(2017,2019)$ built a food web model at the site of Courseulles-sur-mer OWF construction to describe the situation "before" the construction of the wind farm and then performed simulation to analyse the potential impact of the reef and reserve effect (spatial restriction of fisheries for safety measures) on the ecosystem structure and functioning.

This holistic view of the OWF effect on the ecosystem through trophic web modelling could be replicated on other potential installation sites, and used to analyse the long-term reef and reserve effects in the context of global change. Using quantitative modelling to assess cumulative impacts during OWF development would allow bringing new knowledge to policy makers. Results could also be used by the project owner and the "Design Office", which have the responsibility to provide the Environmental Impact Assessment. However, the main drawback that could limit the utilisation of EwE models for management purposes are that model validations are rare, which may lead to a problem of "quality assurance" (Heymans et al., 2016). In addition, this problem of "quality assurance" is compounded by the fact that the data used (biomass and stomach content) to build Ecopath models are often not collected from the study site (same sediment type, depth, and season) but from literature which can induce a bias in the model and so compromise the quality of the results of the model (Plagányi and Butterworth, 2004).

Thus, in the context of OWF development and cumulative impacts there is an urgent need to validate models in order to test the predictions. For that, the validation should be an integral part of the modelling process. However, it is necessary to have an independent data set with information not use in the model inputs.

Concerning EwE models, special attention has been given to the validation of functional compartments trophic levels calculated by Ecopath using Stable Isotope Analyses (SIA) (Kline et Pauly, 1998; Pauly et al., 1998; Polunin et Pinnegar, 2000; Dame and Christian, 2008; 
Nilsen et al., 2008; Milessi et al., 2010; Navarro et al., 2011; Lassalle et al., 2014; Deehr et al., 2014). Compared to modelling, SIA constitutes a completely different approach to analyse trophic interactions within ecosystems (Fry et al., 1987) and the $\delta^{15} \mathrm{~N}$ value can be used to describe the trophic level of consumers (Hobson et Welch 1992; Le Loc'h et al., 2008). This approach is based on the fact that there is a relationship between the isotopic signatures of consumer and their prey (Peterson and Fry, 1987). When a predator consumes its prey, there is an energy transfer and the isotopic nitrogen values show a predictable increase in the isotopic ratio between 0.5 and 5\%o across trophic levels (Minagawa and Wada, 1984; Post, 2002). Despite the wide use of both EwE and SIA, few attempts have been made to compare these methods (Dame and Christian, 2008, Lasalle et al., 2014).

In this study, EwE models from two locations were assessed: the site of the future Courseulles-sur-mer Offshore Wind Farm (CSM OWF) (Raoux et al., 2017), and the future Dieppe-Le-Tréport (DLT OWF) (Pezy et al., 2018 b; Pezy et al., in press). The trophic levels estimated from these two models were compared using trophic levels estimated from independent nitrogen isotope data.

\section{Materials and methods}

\subsection{Study area}

The eastern English Channel (eEC), where the CSM OWF and DLT OWF will be built in the next years, is a shallow epi-continental area located between France and England. It is about $35000 \mathrm{~km}^{2}$ and it is delimited by the Cotentin peninsula in the west and the Dover Strait to the east. The maximum water depth never exceeds $70 \mathrm{~m}$ in the trench running through the centre of the English Channel (Carpentier et al., 2009). The tidal range is greater than $5 \mathrm{~m}$ on the French coast but is closer to $2 \mathrm{~m}$ on the English side (Dauvin and Lozachmeur, 2006). These currents play an essential role in the sediment (Larsonneur et al., 1982) and benthic communities (Cabioch and Gentil, 1975; Dauvin, 2015) distributions. The eEC is also the focus of many human activities such as transportation, fishing, sediment deposit, and sediment extraction (Dauvin and Lozachmeur, 2006; Dauvin, 2012) and is considered by Halpern et al. (2008) as one of the most anthropized sea of the world. 
2.1.1 The Courseulles-sur-mer Offshore Wind Farm (CSM OWF) project

129 The CSM OWF will be located 10 to $16 \mathrm{~km}$ offshore from the Calvados coast between 31 and

130

131

132

133

134

135

136

137

138

139

140

141

142

143

144

145

146

147

148

149

150

151

152

153

154

155

156

157

158

159 $34 \mathrm{~m}$ of depth. It will be located on the coarse sand and gravels benthic communities of the Bay of Seine (Fig. 1). The OWF will represent an area of $50 \mathrm{~km}^{2}$. A total of 75 turbines (each 6 MW) capable of producing $450 \mathrm{MW}$ will be installed by Eoliennes Offshore du Calvados" (EOC) in the next years. The monopile foundation will have a diameter of $7 \mathrm{~m}$ and will be driven into the seabed. The wind farm turbines will be connected via an interarray network consisting of $33 \mathrm{kV}$ AC cables which will link up to an offshore transformer substation located within the wind farm. From this station, power will be exported via two 225 kV AC marine cables.

\subsubsection{Dieppe-Le Tréport Offshore Wind Farm (DLT OWF) project}

The prime contractor of the project is "Eoliennes en mer Dieppe-Le Tréport", a subsidiary of Engie (formerly named GDF Suez). The proposed OWF will be located at distances of $15.5 \mathrm{~km}$ and $17 \mathrm{~km}$ offshore from the coast off Le Tréport and Dieppe, respectively (Figure 1). The water depth ranges from 12 to $25 \mathrm{~m}$. The OWF will cover a total area of approximately 92 $\mathrm{km}^{2}$, and will comprise 62 turbines with a capacity of $8 \mathrm{MW}$ each giving a combined nameplate capacity of $496 \mathrm{MW}$. The foundations are composed of jacket structures. As for the CSM OWF, wind farm turbines will be connected via an interarray network consisting of $33 \mathrm{kV}$ AC cables which will link up to an offshore transformer substation located within the wind farm. From this station, power will be exported via two $225 \mathrm{kV}$ AC marine cables to the continent.

$<$ Figure 1>

\subsection{Data collection}

\subsubsection{Trophic modelling approach}

\subsubsection{The pre-existing Ecopath models}

In order to gain further knowledge on the ecosystem structure and functioning before the construction of the CSM OWF and the DLT OWF, two Ecopath models (Polovina, 1984; Christensen and Walters, 2004; Christensen et al., 2008) describing the initial state of the both sites were built (Raoux et al., 2017; Pezy et al., 2018. Ecopath is a mass-balance (i.e. neglecting year-to year changes in biomass compared to flow values) single-solution model 
160

161

162

163

164

165

166

167

168

169

170

(i.e. returning only one value per flow) in which the ecosystem is represented by functional groups, which are composed of species or group of species with ecological or biological similarities. Each functional group is parameterized with biomass $\left(B, \mathrm{gC} \mathrm{m}^{-2}\right)$, production to biomass ratio $\left(P / B\right.$, year $\left.{ }^{-1}\right)$, consumption to biomass ratio $\left(Q / B, y^{-1}\right)$ and a matrix diet which represents the interactions between predators and prey in the ecosystem.

The parameterization of an Ecopath model is based on two master equations. The first one is the balance equation, which describe the production term:

$$
\text { Production }=\text { Catch }+ \text { Predation }+ \text { Biomass accumulation }+ \text { Net migration }+ \text { Other mortality }
$$

The second equation ensures energy balance for each trophic group:

$$
\text { Consumption }=\text { Production }+ \text { Respiration }+ \text { Unassimilated food }
$$

The CSM Ecopath model consisted of 37 compartments ranging from primary producers (phytoplankton) to top predators (sea birds and marine mammals). In the model, fish were grouped into 18 groups; 6 functional groups (sharks and rays, gurnards, piscivorous, planktivorous, benthos feeders, and otherflatfish) and 12 single species compartments (mackerel (Scomber scombrus), European seabass (Dicentrarchus labrax), Atlantic cod (Gadus morhua), whiting (Merlangius merlangus), Atlantic horse mackerel (Trachurus trachurus), pouting (Trisopterus luscus), poor cod (Trisopterus minutus), European pilchard (Sardina pilchardus), European sprat (Sprattus sprattus) sea bream (Spondyliosoma cantharus), common sole (Solea solea), and European plaice (Pleuronectes platessa)) (Raoux et al., 2017). Benthic invertebrates were grouped into four functional groups: predators, filter feeders, bivalves and deposit feeders (Raoux et al., 2017). The benthic cephalopods, benthopelagic cephalopod, suprabenthos, zooplankton, bacteria, primary producer, and detritus were represented by one group respectively. The seabirds were grouped into two groups and marine mammals into four groups. 26 of the organism groups were obtained from sampling studies.

The DLT Ecopath model was composed of 28 compartments from primary producers to marine mammals. Fish were grouped into five groups (whiting, Ammodytidae, fish benthos feeders, demersal flatfish, and pelagic planktivorous fish). Benthic invertebrates were 
192

193

194

195 196

197

198

199

200

201

202

203

204

205

206

207

208

209

210

211

212

213 214

215

216

217

218

divided into 13 groups with a special subdivision for 6 of these groups (consumed (C) and non consumed (NC)): Branchiostoma lanceolatum, predators ( $C \& N C)$, scavengers (C \& NC), filter feeders (C \& NC), selective deposit feeders (C \& NC), non-selective deposit feeders (C \& $N C)$, grazers $(C \& N C)$. The consumed organisms were those where the species were found in the fish stomach contents. The cetaceans, seals, cephalopods, meiofauna Merosuprabenthos, holosuprabenthos, holozooplankton, bacteria, primary producer and detritus were represented by one group respectively. 21 of the functional groups were obtained from sampling operations (following methods described by Pezy et al., 2019).

The calculated Pedigree indices for these two models were 0.52 and 0.73 for the CSM Ecopath Model and the DLT Ecopath model respectively. These values were calculated from the EwE pedigree routine which quantifies the input parameter uncertainties (Christensen and Walters, 2004).

A full description and sources of information of the input and output parameters of the CSM and the DLT Ecopath models can be found in Raoux et al. (2017) and Pezy et al. (2018) respectively.

\subsubsection{Trophic Level in Ecopath}

The Trophic Level (TL) defines the trophic position of an organism within the food web (Lindeman, 1942). Ecopath allows calculating a TL for each functional group in the model.

The formula corresponds to the weighted average of the trophic levels of the prey of a functional group, with primary producers and non-living material set at a level of 1 :

$$
T L_{j}=1+\sum_{i=1}^{N} D C_{j i} T L_{j} \text { (Eq. 1) }
$$

where $D C_{j i}$ is the fraction of the prey $\mathrm{i}$ in the diet of the predator $\mathrm{j}$. 
2.2.2 Stable isotopes analyses

220

221

222

223

224

225

226

227

228

229

230

231

232

233

234

235

236

237

238

239

240

241

242

243

244

245

246

247

248

249

\subsubsection{Sampling and samples preparation}

Cephalopods were sampled from the GOV ("Grande ouverture Verticale"= high opening) bottom trawl survey in the Bay of Seine during the CGFS (Channel Ground Fish Survey) survey conducted in October 2009 by IFREMER. Other samples of benthic invertebrates were sampled at the site of implantation of the future CSM OWF in October 2015 using a Rallier du Baty dredge.

Fish and benthic invertebrates were collected at the site of the implantation of the future DLT OWF in February 2016 using a $3 \mathrm{~m}$ beam trawl and with a $0.1 \mathrm{~m}^{2}$ Van Veen grab respectively.

130 samples corresponding to nine species were analysed for nitrogen stable isotope to study the trophic level of each species at the CSM future OWF and 102 samples corresponding to 16 species at the DLT future OWF (Table 1 and Table 2). All samples were kept frozen until processed in laboratory. The preparation of the tissue for stable isotopic analyses varied according to taxon. However, we chose to collect the muscle because the nitrogen isotopic signature of the latter is less variable over time than tissues from other organs such as the digestive gland or heart tissue (Pinnegar and Polunin, 1999). For bivalves, a sample was taken for the abductor muscle, for cephalopods, a mantle tissue was taken, for crabs a mantle tissue was taken from chelipeds, for ophiurid a sample was taken from the arms, for sea urchins, the muscle of the lantern of Aristotle was used and for fish a sample of white dorsal muscle was taken.

$<$ Table 1>

$<$ Table 2>

All samples collected were oven dried $\left(60^{\circ} \mathrm{C}\right.$ for $\left.48 \mathrm{~h}\right)$ and then each dried sample was ground into a homogeneous powder using a mixer mill. Approximately $1 \mathrm{mg}$ of powder was weighed into small tin cups. Isotopic analyses were performed with elemental analyser EA 3000 (EuroVector) coupled with a mass spectrometer (Pinnegar and Polunin, 1999) at the 
250

251

252

253

254

255

256

257 258

259

260

261

262

263

264

265

266

267

268

269

270

271

272

273 It is worth to note that published isotopic analyses (Trophic Levels) of 23 taxa (zooplankton,

274 benthic invertebrates and fish) sampled in October 2009 in the Bay of Seine were also used

275 (Kopp et al., 2015) for the comparison of the TLs calculated from the CSM Ecopath with

276 those calculated from SIA. Isotopic results are detailed for all species sampled in the Bay of

277 Seine in Kopp et al. (2015).

278

Plateau d'Analyse d'Isotopie de Normandie (PLAtin, SFR ICORE) at the University of Caen Normandie (France) and at the LEMAR laboratory (Brest University, France).

Results are expressed in standard $\delta$ notation based on international standards $\left[\mathrm{N}_{2}\right.$ for $\delta{ }^{15} \mathrm{~N}$ (Peterson and Fry, 1987)] according to the following the equation:

\subsubsection{Trophic level calculation from the isotopic analyses}

The trophic level of each species was calculated according to the following equation (Minagawa et Wada, 1984):

where $\delta^{15} \mathrm{~N}_{\text {organism }}$ is the isotopic signatures of the organism, $\Delta \mathrm{N}$ is the average $\delta^{15} \mathrm{~N}$ enrichment from prey to predator assumed to be 3.4\%o (Minagawa et Wada, 1984) and the $\delta{ }^{15} \mathrm{~N}_{\text {base }}$ is the mean value of a species close to the trophic web base chosen as trophic baseline and $\lambda$ its trophic level. In our study, the benthic filter feeders, Aequipecten opercularis (Linnaeus, 1758), was used to establish isotopic baseline as this species integrates the short term spatial and temporal variability displayed by primary producers (Jennings and Warr, 2003). Thus, $\lambda=2.18$. 


\subsection{Comparison between Ecopath mass balanced model and isotope results}

280

The correlation between TL derived from SIA and those derived from the two Ecopath models were tested using the Spearman-rank correlation coefficient test (Zar, 1984). In the case of multi-species functional groups, the TL of the functional group was calculated as the mean TL of the species within the functional group weighted by their biomass proportions. The same method was applied to calculate the TL of multi-species functional groups from SIA.

\section{Results}

Results showed that the TLs estimated by the both Ecopath mass balanced models (CSM and DLT) were highly and positively correlated with the SIA (CSM: $r_{\text {Spearman }}^{2}=0,79 ; p<0.0001$ (Figure 2; Table 1); DLT: $r_{\text {Spearman }}^{2} 0,95 ; p<0.0004$ (Figure 3 ; Table 2).

$<$ Figure 2>

$<$ Table 1 >

In fact, the Figure 2 revealed that half of the points are located either above or below the 1:1 line of perfect agreement (or first bisector) in the range of TLs being studied. This result suggested that the EwE approach tended to slightly underestimate the trophic positions of the functional groups located above the first bisector and to slightly over estimate the trophic positions of the functional groups located under the first bisector. For instance, according to the CSM Ecopath model, the zooplankton presented a TL of 2 whereas the zooplankton TL derived from SIA revealed a TL of 2.56. On the same line, the EwE approach also underestimated the TLs of the following groups: Benthopelagic cephalopods, mackerel, European sea bass, Atlantic horse mackerel, gurnard, European pilchard, European sprat, sea bream and Benthic inv, predators. However, the EwE approach overestimated the TL of the following functional groups: Benthic cephalopods, sharks and rays, Atlantic cod (Gadus morhua), whiting (Merlangius merlangus), pounting (Trisopterus luscus), poor cod (Trisopterus minutus), fish benthos feeders, other flat fish, King Scallops (Pecten maximus) and Benthic inv, deposit feeders. In addition, perfect agreements were found for two compartments, one mono-species functional group corresponding to the plaice (Pleuronectes platessa) (17), and a multi-species functional group corresponding to the bivalves (20) (Figure 2; Table 1). Finally, the cephalopods showed the biggest difference 
between the TLs estimated by both methods. This difference did not exceed $20 \%$ for any of the studied trophic compartment.

$<$ Table 2>

313 Concerning the comparison of the TLs derived from the DLT Ecopath model and those from SIA, the results showed that most of the points were located under the first bissector suggested that the EwE approach tended to slightly overestimate the trophic positions of the functional groups located under the first bisector (Figure 3; Table 2). For instance, the EwE approach overestimated the TLs of the following functional groups: fish benthos feeders, flat fish, benthic invertebrates not consumed and the benthic invertebrates filter feeders not consumed. However, the EwE approach underestimated the TL of the benthic invertebrates scavengers not consumed. In fact, according to the DLT Ecopath model, this functional group presented a TL of 3.36 whereas its TL derived from SIA revealed a TL of 3.2 (Figure 3, Table 2). However, it is worth noting that these results were based on a low number of trophic groups and so they should be taken with precaution.

\section{Discussion}

\subsection{Importance of local data}

327 The objective of the present study was to evaluate the CSM OWF model and the DLT OWF model through the comparison of the TLs computed by these two models with TLs estimated from independent nitrogen isotope data. Results showed that TLs estimated by the Ecopath mass balanced models were consistent with the TLs estimated by the SIA as an independent test of validity. These results suggested that diet data use in the CSM Ecopath model and in DLT Ecopath were of good quality and highlighted the importance to build model based on high-quality source data. In addition, these results are consistent by the high value of the pedigree index of these two Ecopath models. In, fact the pedigree index of the CSM Ecopath model (0.5) and of the DLT Ecopath model (0.7) are situated at the maximum of the range

336 (0.16 to 0.7) reported in Morissette (2007). These pedigree high values can be explained by 337 the fact that most of functional group biomass data, in the two models, were obtained from 338 local, highly replicated and detailed sampling (Raoux et al., 2017; Pezy et al., 2018). In 339 addition, the fish diet compositions of the models were derived from local stomach content 
studies (Raoux et al., 2017; Pezy et al., 2018). It is worth to note that in most cases, Ecopath models are built with biomass data not collected from the study site but using literature data that can induce a bias in the model. This is mainly due to the lack of data in many ecosystem studies. In addition, the diet matrix used to build Ecopath models is not always based on local stomach contents which can also induce a bias in the model and so can compromise the Ecopath mass balance results (Plagányi and Butterworth, 2004). In fact, as pointed out by Kopp et al. (2015), marine organism diet can vary significantly between individuals of a given species in different areas. In additions, there can be significant temporal and spatial variability in the diet of marine organisms or during ontogenetic shift (Grangeré et al., 2012, Gaudron et al., 2016). Thus, highlight the importance of site-associated data in the construction of the EwE model.

\subsection{Comparison of the TLs derived from the EwE approach and SIA}

The popular utilisation of both the Ecopath mass balanced model and SIA make their comparison and cross validation highly relevant. However, to date very few attempts have been made to validate the Ecopath model results with results from SIA. Among these few attempts, Kline and Pauly (1998), Nilsen et al. (2008), Milessi et al. (2010), Lasalle et al. (2014), Dheer et al. (2014) also found a positive correlation between the TLs estimated by the EWE and the SIA approach. However, Dheer et al. (2014) highlighted that the EWE approach tended to estimate incorrectly the TLs of the detritivorous species. This can be explained by the fact that in Ecopath, a TL of 1 is automatically associated to detritus leading to an underestimation of TLs compared to SIA (Nilsen et al., 2008; Navarro et al., 2011).

Other potential factors could partly explain the deviation observed between the TLs derived from the two Ecopath models and those calculated from SIA. First, the temporal scale associated with the methods. In Ecopath, TLs are commonly calculated based on data from stomach content analyses, which only records what a predator has eaten recently, whereas the SIA provide information on diet integrated over a period of several weeks or months (Stowasser 2006). In this perspective, collecting muscle tissue is important since nitrogen isotopic signature has less temporal variability than tissue from other organs such as the digestive gland (Pinnegar and Polunin, 1999). This is what we did in this study. A second

371 potential source of discrepancy between the two approaches could be the use of a standard 
isotopic fractionation values (in the calculation of TLs with the SIA approach). The value of

$3733.4 \%$ used in this study is considered as a robust average for $\delta^{15} \mathrm{~N}$ isotopic fractionation

374 (Minagawa and Wada, 1984) but it can range from 0.5 to 5.5\%o (Post, 2002). The

375 fractionation and isotopic signature can also vary among and within species, and at different

376 stages of development according to their growth rate (DeNiro and Epstein 1978, 1981;

377 Weidel et al., 2011), and as a function of the sea temperature (Barnes et al., 2007).

378 Moreover, feeding differences and fish migration between locations can also cause variation

379 in $\delta^{15} \mathrm{~N}$ values (Deegan and Garritt, 1997). Finally, the aggregation of species within

380 compartments in the Ecopath models, and the resulting composition of the compartments

381 can influence the TL calculation, and could partly explain the deviation between the two 382 approaches. In this study, aggregation and definition of the functional groups were based on

383 the biological and ecological characteristics of the species, such as their food preference, 384 size, and commercial importance, as well as on data availability (Raoux et al., 2017; Pezy et 385 al., 2018). However, the difference observed in the zooplankton TL could be explained by the 386 fact that the CSM Ecopath model has only one compartment of zooplankton including both 387 prey (mesozooplankton) and predators (copepods), whereas SIA were made only on 388 copepods, which have a higher trophic level than mesozooplankton. Moreover, the SIA were 389 done on copepods that had not undergone fasting, which could introduce a bias in isotopic 390 analysis. Finally, the differences observed in the cephalopods TLs could be explained by the 391 fact that the prey species with a low trophic level are often digested more rapidly than prey 392 species of higher trophic levels, and would therefore be underestimated during stomach 393 analyses. Finally, it is worth noting that the results from the DLT

\section{Conclusion}

396 In the context of the energy transition, the French government is planning the construction 397 of OWFs in the next decade. Several studies have been done to document the environmental 398 conditions and ecosystem functioning in selected sites before the OWF construction. 399 However, these studies endeavor to consider the sensitivity of some ecological 400 compartments, but they fail in taking into account the trophic links between the 401 compartments. Thus, there is lacking holistic studies on the effects of the OWF constructions 402 and operation. Trophic web models appear to be a good complementary approach to the 403 traditional OWF impact assessments. They allow to consider the ecosystem as a whole, and 
404

405

406

407

408

409

410

411

412

413

414

415

416

417

418

419

420

421

422

423

424

425

426

427

428

429

430

431

432

433

434

to simulate the effects of the OWF construction on the ecosystem structure and functioning (Raoux et al., 2017, 2019; Pezy et al., 2018b). This holistic view of the OWF effects on the ecosystem could with advantage be replicated on other site in the English Channel, and a potentially useful to analyses the long-term OWF effects in the context of climate change (Pezy et al., 2018b). In order to use these models for management purposes, there is an urgent need to validate these models to better simulate the potential impacts associated with this OWF development. In this study, we used isotope ratios of nitrogen as a validation tool for determining the trophic levels accuracy computed by two Ecopath models that describe the ecosystem before the implantation of two futures OWF (CSM and DLT OWF). Results showed a good correlation between Ecopath-calculated trophic levels of the two ecosystems and the $\delta^{15} \mathrm{~N}$ values. These results indicated that the diet data used for the two Ecopath models were of good quality. However, as mentioned below these results must be taken with precaution as they are based on only two cases and the results from DLT case were based on a low number of trophic groups. Nonetheless, the SIA seems to be a good independent tool to validate Ecopath models. SIA could allow to quantify the uncertainty associated with the diets of the different compartments, and could complement the result of the pedigree index already in use in Ecopath. Ideally, isotopic analyses should be done before the model construction, and they could be used to define the model trophic compartments. In the context of OWF development and cumulative impacts, we strongly believe that this step of validation is essential in order to use these models and simulations by policy makers.

\section{ACKNOWLEDGEMENTS}

This work was co-funded by the Normandie Region and by the company "Eoliennes Offshore du Calvados" (EOC) to support Aurore Raoux PhD. It was also funded by the ANRT (Eoliennes en mer Dieppe-Le Tréport and the French State) to support Jean-Philippe Pezy PhD. We acknowledge, for their help in the data sampling, the captain and the crew of the Oceanographic Vessel "Celtic Warrior". We also acknowledge Lilia Leconte, for her help in the sample preparation of the specimens collected at the site of implantation of the future DLT OWF. The isotopic analyses of the Courseulles-sur-mer were funded by the UMR BOREA and the Trophik project (ANR/FEM EMR-ITE 2015). We also acknowledge, the Plateau d'Analyse d'Isotopie de Normandie (PLAtin, SFR ICORE) at the University of Caen (France) 
435 and the LEMAR laboratory (Brest, France) for their help in the isotopic analyses and more 436 particularly François Le Lo'ch and Jean-Marie Munaron. The authors are also grateful to M. 437 Haraldsson for revising the English style and grammar. 


\section{References}

Bailey, H., Brookes, K.L., Thompson, P.M., 2014. Assessing environmental impactsof offshore wind farms: lessons learned and recommendations for the future.Aquat. Biosyst. 10, 113.

Barnes, C., Sweeting, C.J., Jennings, S., Barry, J.T., Polunin, N.V., 2007. Effect of temperature and ration size on carbon and nitrogen stable isotope trophic fractionation. Funct. Ecol. 21, 356-62.

Cabioch, L., Gentil, F., 1975. Distribution des peuplements benthiques dans la partie orientale de la baie de Seine. C. R. Séances Acad. Sci. Paris. 280, 571-574.

Carpentier, A., Martin, C.S., Vaz, S., 2009. Channel Habitat Atlas for marine Resource Management, final report / Atlas des habitats des resources marines de la Manche orientale, rapport final (CHARM phase II). Interreg 3a Programme. IFREMER, Boulognesur-Mer, France. 626 pp.

Christensen, V., Walters, C.J., 2004. Ecopath with Ecosim: methods, capabilities and limitations. Ecol. Model. 172, 109-139.

Christensen, V., Walters, C.J., Pauly, D., Forrest, R., 2008. Ecopath with Ecosim version 6 User Guide. Lensfest Ocean Futures Project. 235 pp.

Colléter, M., Valls, A., Guitton, J., Morissette, J., Arreguín-Sánchez, F., Christensen, V., Gascuel, D., Pauly, D., 2013. EcoBase: a repository solution to gather and communicate information from EwE models. Fisheries Centre Research Reports. UBC Fisheries Centre

Colléter, M, Valls, A, Guitton, J, Gascuel, D, Pauly P, Christensen, V., 2015. Global overview of the applications of the Ecopath with Ecosim modelling approach using the EcoBase models repository. Ecol. Model. 302, 42-53.

Dame, J.K., Christian, R.R., 2007. A statistical test of network analysis: can it detect differences in food web properties? Ecosystems 10, 906-923.

Dauvin, J.C., Lozachmeur, O. 2006. Mer côtière à forte pression anthropique propice au développement d'une Gestion Intégrée : exemple du bassin oriental de la Manche (Atlantique nord-est). VERTIGO, 7, 1-14.

Dauvin, J.C., 2012. Are western and eastern basin of the English two separate ecosystems. Mar. Pollut. Bull. 64, 463-71.

Dauvin, J.C., 2015. History of benthic research in the English Channel: from general patterns of communities to habitat mosaic description. J. Sea. Res. 100, 32-45.

Deegan, L.A., Garritt, R.H., 1997. Evidence for spatial variability in estuarine foodwebs. Mar.Ecol. Prog. Ser. 147, 31-47.

Deehr, R.A., Luczkovich, J.J., Hart, K.J., Clough, L., Johnsons, B. Johnson, J.C. 2014. Using stable isotope analysis to validate effective trophic levels from Ecopath models of areas closed and open to shrimp trawling in core sound. Ecol. Mod. 282, 1-17.

DeNiro, M.J., Epstein, S., 1978. Influence of diet on the distribution of carbon isotopes in animals. Geochim. Cosmochim. Acta. 42, 495-506.

DeNiro, M. J., Epstein, S., 1981. Influence of diet on the distribution of nitrogen isotopes in animals. Geochim. Cosmochim. Acta. 45, 341-51

Fry, B., Macko, S.A., Zieman, J.C. 1987. Review of stable isotopic investigations of food-webs in seagrass meadows. In: Duraki, M.J., Phillips, R.C., Lewis, R.R. (Eds.), SubtropicalTropical Seagrasses in the South-Eastern US Florida Dept. Natural Res. 189-209.

Gaudron, S.M., Grangeré, K., Lefebvre, S., 2016. The Comparison of $\delta 13 \mathrm{C}$ Values of a Deposit- and a Suspension-Feeder Bio-Indicates Benthic vs. Pelagic Couplings and Trophic Status in Contrasted Coastal Ecosystems. Estuar. Coast. Shelf. Sci. 39, 731-741. 
Grangeré, K., Lefebvre, S., Blin, J.L., 2012. Spatial and temporal dynamics of biotic and abiotic features of temperate coastal ecosystems as revealed by a combination of ecological indicators. Estuar. Coast. Shelf. Sci. 108,109-118.

Halpern, B.S., Walbridge, S., Selkoe, K.A., Kappel, C.V., Micheli, F., D'Agrosa, C., Bruno, J.F., Casey, K.S., Ebert, C., Fox, H.E., Fujita, R., Heinemann, D., Lenihan, H.S., Madin, E.M.P., Perry, M.T., Selig, E.R., Spalding, M.D., Steneck, R., Watson, R., 2008. A global map of human impact on marine ecosystems. Science. 319, 948-952.

Hobson, K.A., Welch, H.E. 1992. Determination of trophic relationships within a high Arctic marine food web using $\delta 13 \mathrm{C}$ and $\delta 15 \mathrm{~N}$ analysis. Mar. Ecol. Prog. Ser. 84, 9-18.

Heymans, J.J., Tomczak, M.T., 2016. Regime shifts in the Northern Benguela ecosystem: challenges for management. Ecol. Model. 331, 151-159.

Heymans, J.J., Coll, M., Link, J.S., Mackinson, S., Steenbeek, J., Walters, C. \& Christensen, V., 2016. Best practice in Ecopath with Ecosim food-web models for ecosystem-based management. Ecol. Model. 123-128.

Jennings, S., Warr, K.J., 2003. Smaller predator-prey body size ratios in longer food chains. P. R. Soc. London. 270, 1413-1417.

Kline, T., Pauly, D., 1998. Cross-validation of trophic level estimates from a mass balance model of Prince William Sound using 15N/14N data. In: Funk, F., Quinn II, T.J., Heifetz, J., Ianelli, J.N., Powers, J.E., Schweigert, J.F., Sullivan, P.J., Zhang, C.-I. (Eds.), Fishery Stock Assessment Models. Alaska Sea Grant College Program Report No AK-SG-98-01, University of Alaska, Fairbanks, USA. 693-702.

Koop, D., Lefebre, S., Cachera, M., Villanueva, M.C., Ernande, B., 2015. Reorganization of a marine trophic network along an inshore-offshore gradient due to stronger pelagicbenthic coupling in coastal areas. Prog. Oceanogr. 130, 157-171.

Langseth, B.J., Rogers, M., Zhang, H., 2012. Modelling species invasions in Ecopath with Ecosim: an evaluation using Laurentian Great Lakes models. Ecol. Model., 247, 251-261.

Larsonneur, C., Bouysse, P., Auffret, J.P., 1982. The superficial sediments of the English Channel and its western approaches. Sedimentology. 29, 851-864.

Lassalle, G., Chouvelon, T., Bustamante, P., Niquil, N., 2014. An assessment of the trophic structure of the Bay of Biscay continental shelf food web: Comparing estimates derived from an ecosystem model and isotopic data. Prog. Oceanogr. 120, 205-215.

Le Loc'h, F., Hily, C., Grall, J., 2008. Benthic community and food web structure on the continental shelf of the Bay of Biscay (North Eastern Atlantic) revealed by stable isotopes analysis. J. Mar. Syst. 72, 17-34.

Leung, D., Yang, Y., 2012. Wind energy development and its environmental impact: A review. Renew. Sust. Energ. Rev. 16. doi: 10.1016/j.rser.2011.09.024.

Ludwig, D., 2002. A quantitative precautionary approach. Bull. Mar. Sci. 70, 485-497.

Milessi, A.C., Calliari, D., Rodríguez-Grana, L., Conde, D., Sellanes, J., Rodríguez-Gallego, L., 2010. Trophic mass-balance model of a subtropical coastal lagoon, including a comparison with a stable isotope analysis of the food-web. Ecol. Model. 221, 28592869.

Minagawa, M., Wada, E., 1984. Step wise enrichment of $15 \mathrm{~N}$ along food-chains: further evidence and the relation between $\mathrm{d} 15 \mathrm{~N}$ and animal age. Geochimica. 48, 1135-1140.

Morissette, L., 2007. Complexity, Cost and Quality of Ecosystem Models and Theirlmpact on Resilience: A Comparative Analysis, with Emphasis on MarineMammals and the Gulf of St. Laurence Zoology. University of British Columbia, Vancouver BC, Canada, pp. 260.

Navarro, J., Coll, M., Louzao, M., Palomera, I., Delgado, A., Forero, M.G., 2011. Comparison 
of ecosystem modelling and isotopic approach as ecological tools to investigate food webs in the NW Mediterranean Sea. J. Exp. Mar. Biol.Ecol. 401, 97-104.

Nilsen, M., Pedersen, T., Nilssen, E.M., Fredriksen, S., 2008. Trophic studies in a high latitude fjord ecosystem: a comparison of stable isotope analyses $(\delta 13 \mathrm{C}$ and $\delta 15 \mathrm{~N})$ and trophic level estimates from a mass-balance model. Can. J. Fish. Aquat Sci. 65, 2791-2806.

Pauly, D., Christensen, V., Dalsgaard, J., Froese, R., Torres, F., 1998. Fishing down marine food webs. Science. 279, 860-863.

Pezy, J.P., Raoux, A., Marmin, S., Balay, P., Niquil, N., Dauvin, J.C. 2017. Before-After analysis of the trophic network of an experimental dumping site in the eastern part of the Bay of Seine (English Channel). Mar. Pollut. Bull. 118, 101-111.

Pezy J.P., Raoux A., Dauvin J.C., 2018a. An ecosystem approach for studying the impact of offshore wind farms: a French case study. ICES Journal of Marine Sciences fsy125, https://doi.org/10.1093/icesjms/fsy125

Pezy, J.P., Raoux, A., Marmin, S., Bailay, P., Dauvin, J.C., 2018b. What are the most suitable indices to detect the structural and functional changes of benthic community after a local and short-term disturbance? Ecol. Ind. 91, 232-240.

Pezy, J.P., Raoux, A., Niquil, N., Dauvin, J.C., in press. Offshore renewable energy development in France with an emphasis on the eastern part of the English Channel: state at the end of 2017. Proceedings of the Conference on Wind Energy and Wildlife Impacts, Estoril, September 2017.

Peterson, B.J., Fry, B., 1987. Stable isotopes in ecosystem studies. Annu. Rev. Ecol. Syst. 18, 293-320.

Pinnegar, J.K., Polunin, N.V.C., 1999. Differential fractionation of d13C and d15N among fish tissues: implications for the study of trophic interactions. Funct. Ecol. 13, 225-231

Plaganyi, E.E., Butterworth, D.S. 2004. A critical look at the potential of Ecopath with Ecosim to assist in practical fisheries management. Afr. J. Mar. Sci. 26, 261-287.

Plaganyi, E.E., 2007. Models for an Ecosystem Approach to Fisheries. FAO Fish. Tech. Pap. No. 477. FAO, Rome, 2007, 108 pp.

Polovina, J.J., 1984. Model of a coral reef ecosystem. The ECOPATH model and its application to French Frigate Shoals. Coral Reefs 3, 1-11.

Polunin, N.V.C., Pinnegar, J., 2000. Trophic-level dynamics inferred from stable isotopes of carbon and nitrogen. CIESM Workshop Series. 12, 69-73.

Post, D.M., 2002. Using stable isotopes to estimate trophic position: models, methods and assumptions. Ecology. 83, 703-718.

Raoux, A., Tecchio, S., Pezy, J.P., Degraer, S., Wilhelmsson, D., Cachera, M., Ernande, B., Lassalle, G., Leguen, C., Grangeré, K., Le loch, F., Dauvin, J.C., Niquil, N., 2017. Benthic and fish aggregation inside an offshore wind farm: Which effects on the trophic web functioning ? Ecol. Indic. 72, 33-46.

Raoux, A., Lassalle, G., Pezy, J.P., Tecchio, S., Safi, G., Ernande, B., Mazé, C., Le loch, F., Lequesne, J., Girardin, V., Dauvin, J.C., Niquil, N., 2019. Measuring sensitivity of two Ospar indicators for a coastal food web model under Offshore Wind Farm construction. Ecol. Ind. 96,728-738.

Stowasser G., Pierce G, J., Moffat C. F., Collins M. A., Forsythe J.W., 2006. Experimental study on the effect of diet on fatty acid and stable isotope profiles of the squid Lolliguncula brevis. J. Exp. Mar. Biol. Ecol 97-114.

Tecchio, S., Tous Rius, A., Dauvin, J.C., Lobry, J., Lassalle, G., Morin, J., Bacq, N., Cachera, M., Chaalali, A., Villanueva, M.C., Niquil, N., 2015. The mosaic of habitats of the Seine 
estuary: Insights from food-web modelling and network analysis. Ecol. Model. 312, 91101.

Weidel, B., Carpenter, S., Kitchell, J., Vander Zanden, M.J., 2011. Rates and components of carbon turnover in fish muscle: insights from bioenergetics models and a whole-lake $13 \mathrm{C}$ addition. Can. J. Fish. Aquat. Sci. 68, 387-99.

Wilding, T.A., Gill, A.B., Boon, A., Sheehan, E., Dauvin, J.C., Pezy, J.P., O’Beirn, F., Janas, U., Rostin, L., De Mesel, I., 2017. Turning off the DRIP ('Data-rich, information-poor') rationalizing monitoring with a focus on marine renewable energy developments and the benthos. Renew. Sust. Energ. Rev. 74: 848-859

Willsteed, E.D., Jude, S., Gill, A., Birchenough, S.N.R., 2018. Obligations and aspirations: A critical evaluation of offshore wind farm cumulative impact assessments. Renew. Sust. Energ. Rev. 82, 2332-2345. 
Figure captions

Figure 1: Location of the Courseulles-sur-Mer future offshore wind farm (which corresponds

596 to the CSM Ecopath model) and of the Dieppe-Le Tréport future offshore wind farm (which corresponds to the CSM Ecopath model) (Modified from Larsonneur et al., 1982)

598

599

600

601

602

603

604

605

606

607

Figure 2: TLs estimated from stable isotopes $\left(T L_{\mid A}\right)$ plotted against their corresponding levels estimated by the Ecopath model ( $\mathrm{TL}_{\text {Ecopath }}$ ) for the CSM OWF trophic web. Invertebrates are represented by rectangles (black: benthic organisms and benthic cephalopods; white: zooplankton) and fish by circles (black: flatfish; grey: demersal fish; white: pelagic fish). See Table 1 for matching between number and functional groups.

004 Figure 3: TLs estimated from stable isotopes $\left(T L_{\mid A}\right)$ plotted against their corresponding levels estimated by the Ecopath model ( $\left.T L_{E c o p a t h}\right)$ for the DLT OWF trophic web. See Table 2 for matching between number and functional groups. 
Table 1: Comparison between the TLs derived from the CSM ecopath model and the TLS

\begin{tabular}{|c|c|c|c|c|}
\hline Number & Functional group & TLs Ecopath & TLs IA & Source for IA \\
\hline 1 & Benthic cephalopods & 3.92 & $3.22 \pm 0.16$ & This study \\
\hline 2 & Benthopelagic cephalopods & 4.07 & $4.22 \pm 0.25$ & Kopp et al., 2015 \\
\hline 3 & Fish, mackerel & 3.14 & $3.30 \pm 0.18$ & Kopp et al., 2015 \\
\hline 4 & Fish, European seabass & 3.75 & $3.98 \pm 0.25$ & Kopp et al., 2015 \\
\hline 5 & Fish, sharks and rays & 4.15 & $3.46 \pm 0.2$ & Kopp et al., 2015 \\
\hline 6 & Fish, Atlantic cod & 4.03 & $3.66 \pm 0.2$ & Kopp et al., 2015 \\
\hline 7 & Fish, whiting & 4.12 & $3.98 \pm 0.25$ & Kopp et al., 2015 \\
\hline 8 & Fish, Atlantic horse mackerel & 3.90 & $4.03 \pm 0.26$ & Kopp et al., 2015 \\
\hline 9 & Fish, gurnard & 3.50 & $3.90 \pm 0.25$ & Kopp et al., 2015 \\
\hline 10 & Fish, pouting & 3.76 & $3.61 \pm 0.23$ & Kopp et al., 2015 \\
\hline 11 & Fish, poor cod & 3.72 & $3.28 \pm 0.21$ & Kopp et al., 2015 \\
\hline 12 & Fish, European pilchard & 2.80 & $2.95 \pm 0.23$ & Kopp et al., 2015 \\
\hline 13 & Fish European sprat & 3.00 & $3.12 \pm 0.16$ & Kopp et al., 2015 \\
\hline 14 & Fish, benthos feeders & 3.76 & $3.48 \pm 0.18$ & Kopp et al., 2015 \\
\hline 15 & Fish, sea bream & 3.20 & $3.71 \pm 0.22$ & Kopp et al., 2015 \\
\hline 16 & Fish, sole & 3.44 & $3.32 \pm 0.18$ & Kopp et al., 2015 \\
\hline 17 & Fish, European plaice & 3.37 & $3.37 \pm 0.17$ & Kopp et al., 2015 \\
\hline 18 & Fish, other flatfish & 3.35 & $3.21 \pm 0.16$ & Kopp et al., 2015 \\
\hline 19 & Benthic inv. predators & 3.07 & $3.22 \pm 0.16$ & This study \\
\hline 20 & Benthic inv. bivalves & 2.10 & $2.11 \pm 0.05$ & This study \\
\hline 21 & King scallop & 2.10 & $2.00 \pm 0.16$ & Kopp et al., 2015 \\
\hline 22 & Benthic inv. deposit feeders & 2.21 & $2.02 \pm 0.024$ & This study \\
\hline 23 & Zooplankton & 2.00 & $2.56 \pm 0.17$ & Kopp et al., 2015 \\
\hline
\end{tabular}


613 Table 2: Comparison between the TLs derived from the DLT Ecopath model and the TLs 614 calculated from SIA

615

\begin{tabular}{|c|c|c|c|c|}
\hline Number & Functional group & TLs Ecopath & TLs IA & Source \\
\hline 1 & Fish benthos feeders & 3.51 & $3.32 \pm 0.16$ & \multirow{5}{*}{ 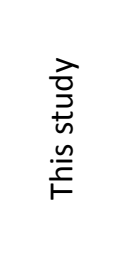 } \\
\hline 2 & Fish flatfish & 3.38 & $3.35 \pm 0.13$ & \\
\hline 3 & Benthic inv. predator not consumed & 3.09 & $2.84 \pm 0.12$ & \\
\hline 4 & Benthic inv. filter feeders not consumed & 2.25 & $2.10 \pm 0.11$ & \\
\hline 5 & Benthic inv. Scavenger not consumed & 3.36 & $3.42 \pm 0.18$ & \\
\hline
\end{tabular}

616

617 


\section{Figure 1}

$0^{\circ} 0^{\prime} 0.00^{\prime \prime}$




620 Figure 2

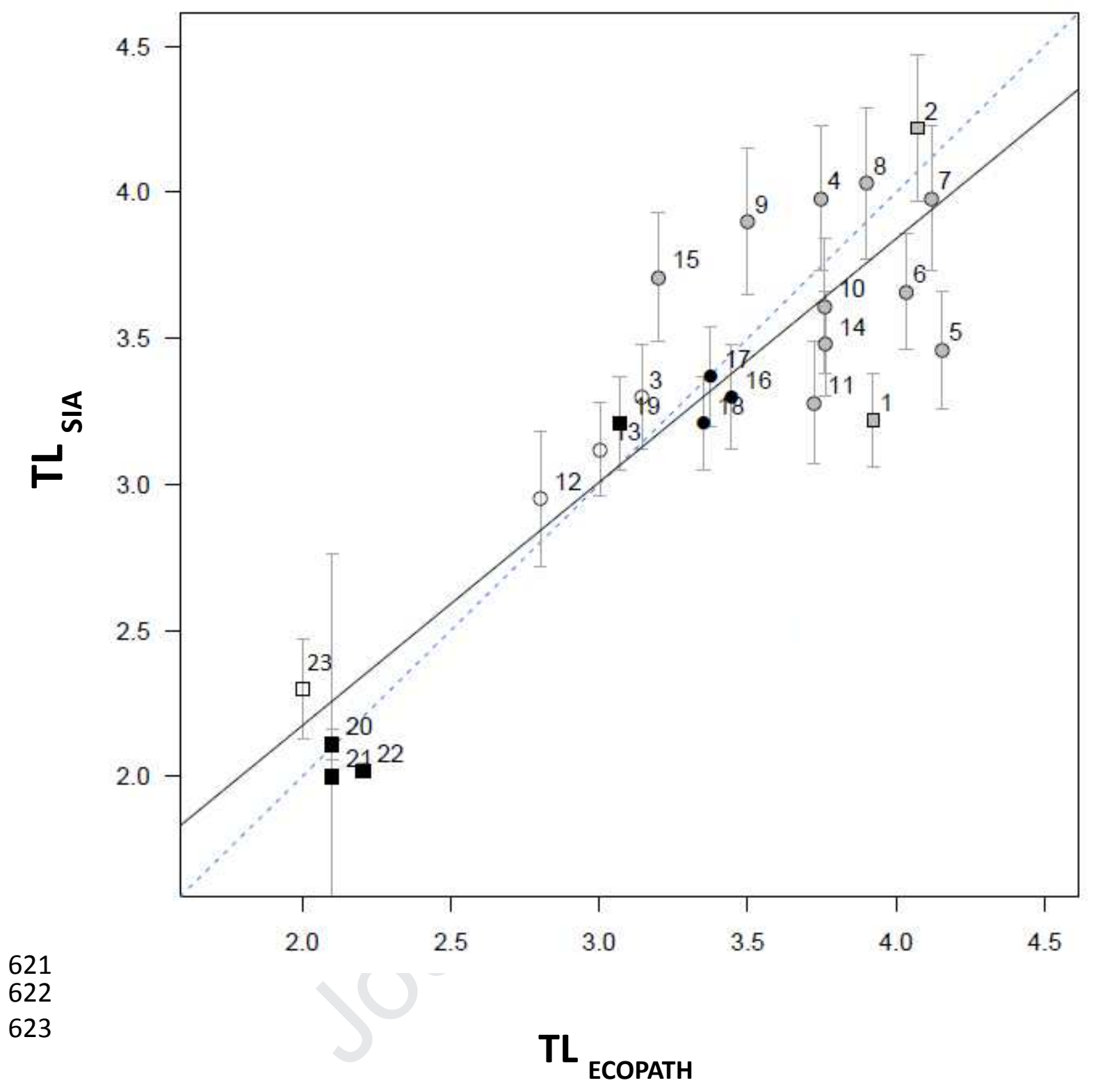


624 Figure 3

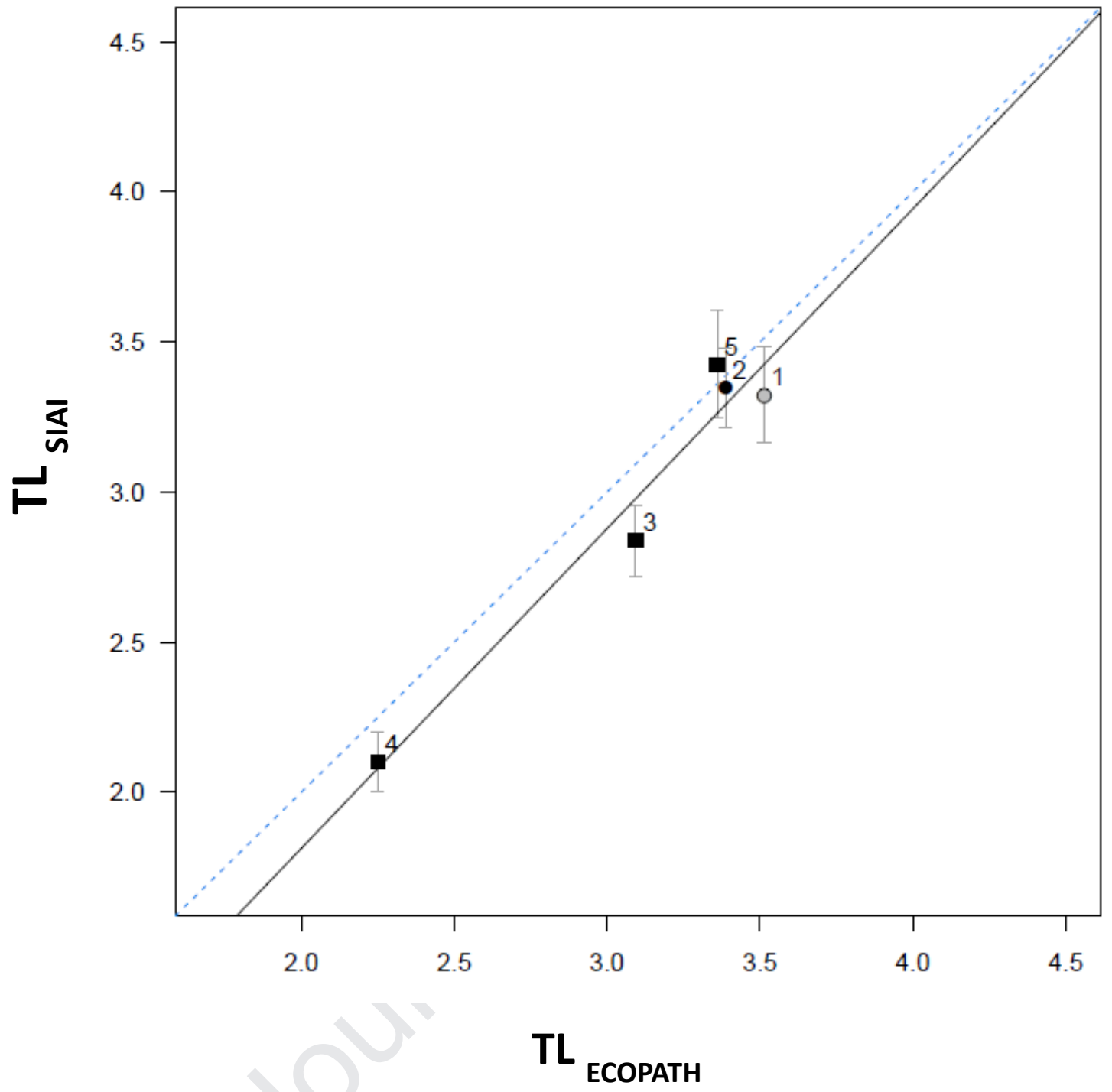


Isotopic analyses, a good tool to validate models in the context of Marine Renewable Energy development and cumulative impacts

Aurore Raoux, Jean-Philippe Pezy, Bruno Ernande, Nathalie Niquil, Jean-Claude Dauvin, Karine Grangeré

\section{HIGHLIGHTS}

- Comparison of trophic web structure by mass-balance modelling and stable isotopic approach

- Clear relationships between trophic levels estimated by models and nitrogen value were found

- Model validation is essential for developing their use by policy makers 


\section{Declaration of interests}

$\bigotimes$ The authors declare that they have no known competing financial interests or personal relationships that could have appeared to influence the work reported in this paper.

$\square$ The authors declare the following financial interests/personal relationships which may be considered as potential competing interests: 